\title{
第51回 日本視能矯正学会
}

\section{教育セミナー}

\section{OCT}

\author{
池田史子
}

群馬大学

光干渉断層計（OCT）は1997年にその 1 号機 が日本に導入された。OCTは非侵襲的に生体で 組織の断層構造を観察できる装置である。生体 眼から実際に病理組織を得ることは困難なため、 生体において網膜の断層像が得られるOCTの登 場は大変画期的であった。初期のOCTは深さ方 向の解像度が $20 \mu \mathrm{m}$ だったが、現在、臨床で使 われている最新の機種では深さ方向の解像度が $3 \sim 5 \mu \mathrm{m}$ と向上し、網膜断面のより詳細な観 察が可能になっている。OCTの発展に伴い、黄 斑円孔、加齢黄斑変性、網膜上膜や糖尿病黄斑 症など、さまざまな黄斑部疾患の病態が解明さ れてきた。さらに、2008 年4 月からはOCT検
查が眼底三次元画像解析として保険診療として 認められ、一般の眼科医院でも OCTが汎用され るようになり眼底疾患の必須診断機器になった。 OCTで得られる網膜断象像は、患者への病状説 明や治療効果の判定など、その有用性は増して いる。今回の講演では、OCT検査で何がわかる のかを実際の症例を提示して解説するとともに、 診断に有用な画像をえるためのコツをお話しす る。現在、日本で使用されているOCTには 7 種 類ほどあり、機種によって撮影の手順は違うた め、撮影手順のポイントとしてはどの機種でも 共通していると思われる点に絞って解説する予 定である。

抄録のみを掲載しています。 